Volume VII - Article 6

\title{
IMPEACHING FINNIGAN AND REALIGNING THE CORROBORATION STANDARD FOR Uninterested Single Witness Testimony with Precedent and Policy ${ }^{1}$
}

\author{
Jessica R. Underwood ${ }^{2}$ \\ Spring 2007 \\ Journal of Technology Law and Policy
}

Copyright (C) University of Pittsburgh School of Law

\section{$\underline{\text { Table of Contents }}$}

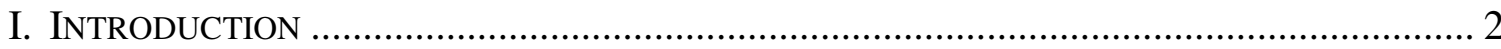

II. BACKGROUND: THOMSON, FINNIGAN, AND THE REUTER FACTORS ................................... 4

A. Corroboration Required Only for Interested Inventors: Thomson, S.A. v. Quixote

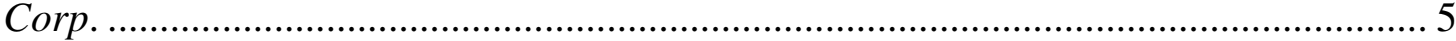

B. Corroboration Required Irrespective of Interest or Inventorship Status: Finnigan

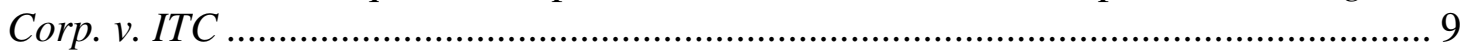

C. Reuter Factors for the Testimony of More than One Witness ................................. 11

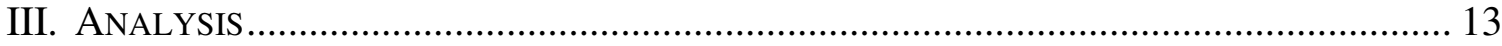

A. Inconsistent Positions by the Federal Circuit......................................................... 13

1. Finnigan's Unsuccessful Attempt to Reconcile Thomson ................................... 14

2. Contradictory Interpretations of the Same Case Precedent ………….................. 17

3. Still Confusion After Finnigan ......................................................................... 20

B. Realigning the Corroboration Standard with Precedent and Policy......................... 21

1. Implementing a More Moderate Standard in Lieu of a Bright-Line Rule ........... 22

2. Rationale and Application of the Corroboration Rule in Case Precedent ........... 24

3. Policy Considerations Weigh Against a Bright-Line Rule …………………....... 28

4. Application of the Reuter Factors for Single Witness Testimony ......................... 31

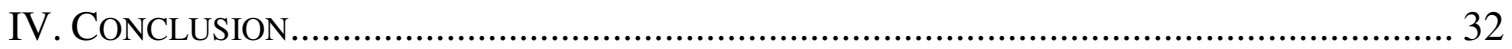

\footnotetext{
${ }^{1}$ A previous version of this article is pending publication in the Federal Circuit Bar Journal, 16.3.

2 Jessica Underwood will be joining Finnegan, Henderson, Farabow, Garrett, \& Dunner as an Associate in the biotechnology group after graduating from DePaul University College of Law in May 2007. The author would like to thank Professor Matthew Sag of DePaul University College of Law for his guidance and support during the completion of this article. The author would also like to gratefully acknowledge Howard Levine of Finnegan, Henderson, Farabow, Garrett, and Dunner for his insightful comments.
} 


\section{INTRODUCTION}

Thomson $^{3}$ and Finnigan ${ }^{4}$ were decided by different panels of Federal Circuit judges with one judge in common, ${ }^{5}$ only four and a half months apart. Both panels addressed whether an uninterested witness's testimony must be corroborated, and both panels reached different outcomes. Although the latter of the two cases, Finnigan, attempted to reconcile the apparent inconsistencies, its craftsmanship suggests a veiled attempt to overrule Thomson, ${ }^{6}$ rather than distinguish it. ${ }^{7}$ Even though most courts have followed Finnigan ${ }^{8}$ instead of Thomson, ${ }^{9}$ Thomson deserves special attention--not only

\footnotetext{
${ }^{3}$ Thomson, S.A. v. Quixote Corp., 166 F.3d 1172 (Fed. Cir. 1999) (before Circuit Judges Rich, Schall, and Gajarsa; opinion by Rich; decided on Jan. 25, 1999).

${ }^{4}$ Finnigan Corp. v. ITC, 180 F.3d 1354 (Fed. Cir. 1999) (before Circuit Judges Rich, Michel, and Lourie; opinion by Lourie; decided on June 9, 1999).

${ }^{5}$ Judge Giles Rich sat on both panels, but passed away on the day that the Federal Circuit issued Finnigan. Judge Giles Rich Dies, The Recorder, July 1999, at S5.

${ }^{6}$ See Engate, Inc. v. Esquire Deposition Servs., L.L.C., 331 F. Supp. 2d 673, 685 (N.D. Ill. 2004) (citing K \& K Jump Start/Chargers, Inc. v. Schumacher Electric Corp., 82 F. Supp. 2d 1012, 1018 n.7 (W.D. Mo. 2000) (overruled on other grounds)) (reasoning that while Thomson has not been overruled, subsequent decisions suggest that its holding may not be viable).

7 See Steven N. Hird, In Finnigan's Wake: Recent Confusing Changes in the Federal Circuit's Requirement for Corroboration for Witness Testimony During Patent Infringement Litigation, 72 U. Colo. L. REV. 257, 259 (2001).

${ }^{8}$ The following cases have relied on Finnigan and required witness testimony to be corroborated despite the witness's level of interest. See, e.g., TypeRight Keyboard Corp. v. Microsoft Corp., 374 F.3d 1151, 1159 (Fed. Cir. 2004); Dow Chemical Co. v. Mee Indus., Inc., 341 F.3d 1370, 1378 (Fed. Cir. 2003); Juicy Whip, Inc. v. Orange Bang, Inc., 292 F.3d 728, 738 (Fed. Cir. 2002); Texas Digital Sys., Inc. v. Telegenix, Inc., 308 F.3d 1193, 1217 (Fed. Cir. 2002). See also Berry Sterling Corp. v. Pescor Plastics, Inc., 215 F.3d 1351, WL 674514, at *4 (Fed. Cir. Aug. 30, 1999) (unpublished).

${ }^{9}$ Engate, 331 F. Supp. 2 d at 685 (stating that the safest option is to operate under the assumption that the corroboration requirement still exists as delineated by Finnigan, even though Thomson has not been overruled); accord Briton v. Loggans, No. 3:04-0177, 2006 WL 2336556, at*3 (M.D. Tenn. Aug. 8, 2006) (slip copy) (acknowledging the Federal Circuit split regarding whether the testimony of non-party witnesses with no personal interest in the case requires corroboration, but opting to follow the 'safest option' and assume the corroboration requirement still exists).

However, Thomson has been cited as authority and followed by courts during their analysis to determine whether the corroboration rule should be applied, as opposed to whether the witness testimony had been sufficiently corroborated. See, e.g., Eisenberg v. Alimed, Inc., 98-1317, 2000 U.S. App. LEXIS 19121, at $* 11-* 12$ (Fed. Cir. Aug. 8, 2000) (unpublished) (holding that the corroboration rule was not applicable to the disinterested witness's testimony regarding her prior use of the invention at hand); $3 \mathrm{M}$ Unitek Corp. v. Ormco Co., 96 F. Supp. 2d 1042, 1050 (C.D. Cal. 2000) (quoting Thomson to determine whether the corroboration rule should be applied and finding that, based on that standard, the testimony of both prior inventors required corroboration); Norian Corp. v. Stryker Corp., 252 F. Supp. 2d 945, 955-56 (N.D. Cal. 2002) (overruled on other grounds) (following Thomson after reasoning that Finnigan did not
} 
because it has not been overruled, ${ }^{10}$ but also because its holding is a natural extension of legal precedent and patent policy that may prove to be the more contoured rule to the issue at hand. Namely, whether an uninterested witness's testimony submitted to prove patent invalidity must be corroborated with other evidence as a bright-line rule or whether courts should have the option to evaluate this testimony on a case-by-case basis. In other words, the issue discussed in the conflicting holdings of Thomson and Finnigan is whether a single witness's testimony is ever sufficient to meet the evidentiary burden of clear and convincing evidence to prove patent invalidity.

In addressing this issue, the Thomson court unequivocally asserted that "corroboration is required only when the testifying inventor is asserting a claim of derivation or priority of his or her invention and is a named party, an employee of or assignor to a named party, or otherwise is in a position where he or she stands to directly and substantially gain by his or her invention being found to have priority over the patent claims at issue." 11 In contrast, the Finnigan court emphatically stated that "corroboration is required of any witness whose testimony alone is asserted to invalidate a patent, regardless of his or her level of interest" as applied to all subsections under $§ 102 .^{12}$

Per statute, courts presume that patents are valid. ${ }^{13}$ Thus, the burden is on the party asserting invalidity to prove it with facts supported by clear and convincing evidence. ${ }^{14}$ This discussion focuses on the defendant's assertion of invalidity for lack of

extend the corroboration requirement to anticipatory-publication cases because, among other reasons, Carella and Thomson would be hard to reconcile with an across-the board corroboration rule). See also Carella v. Starlight Archery, 804 F.2d 135, 138 (Fed. Cir. 1986) ("in some circumstances unsupported oral testimony can be sufficient to prove prior knowledge or use").

${ }^{10}$ See Engate, 331 F. Supp. 2d at 685.

${ }^{11}$ Thomson, 166 F.3d at 1176 (emphasis added).

${ }^{12}$ Finnigan, 180 F.3d at 1367, 1369 (emphasis added).

1335 U.S.C. § 282 (1994); Finnigan, 180 F.3d at 1365.

${ }^{14}$ SSIH Equip., S.A. v. ITC, 718 F.2d 365, 375 (Fed. Cir. 1983). 
novelty based on anticipation of the claims under the subsections of 35 U.S.C. $\S 102 .{ }^{15}$ When the testifying defendant or non-party retained by the defendant attests to the anticipation of the plaintiff's claims, the pivotal issue in the case becomes whether the witness's testimony is sufficient to meet the clear and convincing evidentiary standard. ${ }^{16}$

This article will first discuss the two cases at issue, Finnigan and Thomson, as well as the Reuter factors, which courts use to evaluate the sufficiency of corroborating evidence. Next, this article compares both Finnigan and Thomson's contradictory holdings and examines the two cases' use of inconsistent interpretations of the same case precedent to support their polar positions. Based on this analysis, it appears that Finnigan's attempt to reconcile Thomson creates a false distinction that disregards and ultimately contradicts Thomson's unambiguous holding. Finally, this paper makes a recommendation for a more moderate standard in lieu of a bright-line rule for uninterested witness testimony in order to realign the corroboration requirement's purpose and rationales with established case precedent and policy.

\section{BACKGROUND: THOMSON, FINNIGAN, AND THE REUTER FACTORS}

The Thomson and Finnigan decisions take contradictory approaches to similar sets of facts, evidencing each court's attempt to narrow or broaden the application and scope of the corroboration rule. Read conservatively, the Thomson court pulls away from a bright-line application of the corroboration rule insofar as it gives discretion to the factfinder to evaluate whether the witness's interest in the outcome of the litigation rises

\footnotetext{
${ }^{15} 35$ U.S.C. $§ 102$ (1994). A claimed invention must be novel; if it is not novel, it is "anticipated." Id. A claimed invention can be anticipated by any prior knowledge, publication, invention, sale, or public use of an article or process if it embodies each and every element of the claimed invention. Id.

${ }^{16}$ See Hird, supra note 5, at 265.
} 
to a level that necessitates triggering the corroboration rule. ${ }^{17}$ If the witness is a named party or employee of or assignor to a named party, the corroboration rule is triggered, but Thomson softened this rule by restricting its application only to inventors and cases that involve a claim of derivation or priority. ${ }^{18}$ The court in Finnigan, on the other hand, erected a bright-line application of the corroboration rule to all witnesses, irrespective of inventorship or interest, ${ }^{19}$ and extended the rule's application to all subsections of $\S$ $102 .^{20}$

A. Corroboration Required Only for Interested Inventors: Thomson, S.A. v. Quixote Corp.

In Thomson, the Federal Circuit affirmed the district court's decision sustaining the jury verdict, which held that the plaintiff's patent was invalid as anticipated under 35 U.S.C. $§ 102(\mathrm{~g}) .^{21}$ The jury found anticipation after the defendant presented evidence at trial to show that the patent claims were anticipated by a similar unpatented invention, a laser videodisc, made by a non-party to the suit, MCA. ${ }^{22}$ In sustaining the jury verdict, the district court described evidence in the record that supported that the patented invention's limitations were present in the anticipating invention, stating that

the evidence . . . came from one or more sources: the live testimony of two people who had worked on the MCA's laser videodisc project; an expert's report and portions of his deposition testimony, both of which were read into the record; the expert's exhibits' and certain MCA documents that the expert had reviewed. ${ }^{23}$

${ }^{17}$ See Thomson, 166 F.3d at 1174-76.

${ }^{18}$ See id.

${ }^{19}$ See Finnigan Corp. v. ITC, 180 F.3d 1354, 1369 (Fed. Cir. 1999).

${ }^{20} I d$. at 1367.

${ }^{21}$ Thomson, 166 F.3d at 1173-74.

${ }^{22} I d$. at 1174 ..

${ }^{23} I d$. 
On appeal, the Federal Circuit rejected the plaintiff's argument that the jury verdict was improper because it rested solely on non-corroborated testimonial evidence by two non-party MCA employees. ${ }^{24}$ The Federal Circuit first assumed, for the sake of argument, that the jury verdict rested solely on the testimony of the two former MCA employees. ${ }^{25}$ The court then went on to explain that the facts of Thomson did not require corroboration because the witnesses were non-parties to the suit and their testimony concerned an unpatented prior invention. ${ }^{26}$ Consequently, according to the Federal Circuit, the level of self-interest did not justify triggering the corroboration rule, and, furthermore, the jury had the necessary facts to assess the credibility of the witnesses, even if a degree of self-interest was involved. ${ }^{27}$

As support for this holding, the Federal Circuit acknowledged that while the Supreme Court and Federal Circuit had decided cases with $\S 102(\mathrm{~g})$-type anticipation claims by non-party inventors, ${ }^{28}$ neither court had "directly held whether the corroboration rule must be applied to testimony by non-party inventors that is directed to establishing their invention as anticipating the claims at issue." 29 Instead, according to Thomson, these courts only expressed skepticism toward uncorroborated inventor testimony that attempted to establish priority when the inventor was self-interested in the litigation's outcome and, as a result, tempted to 'remember' favorable facts. ${ }^{30}$ As an

\footnotetext{
${ }^{24} I d$. at $1174-75$.

${ }^{25} \mathrm{Id}$.

${ }^{26}$ Id. at $1174-76$.

${ }^{27} \mathrm{Id}$. at 1176.

${ }^{28}$ Thomson, 166 F.3d at 1175-76 (citing Eibel Process Co. v. Minn. \& Ont. Paper Co., 261 U.S. 45 (1923); Washburn \& Moen Mfg. Co. v. Beat 'Em All Barbed-Wire Co. (Barbed Wire Patent), 143 U.S. 275 (1892); New Idea Farm Equip. Corp. v. Sperry Corp., 916 F.2d 1561 (Fed. Cir. 1990)).

${ }^{29}$ Thomson, 166 F.3d at 1175-76.

${ }^{30}$ Id. at 1176 (citing Price v. Symsek, 988 F.2d 1187, 1194 (Fed. Cir. 1993)) (showing that the testifying inventor's interfering patent claims would be invalidated if he could not establish priority and holding that the board extended the corroboration rule beyond reasonable bounds).
} 
example, the Federal Circuit cited Barbed-Wire, in which the testifying non-party inventors' patents would increase in value if the patent claims were invalidated. ${ }^{31}$ Thus, according to Thomson, the court in that case justifiably required corroboration because the witnesses were interested parties. ${ }^{32}$ Even Reuter, ${ }^{33}$ according to the Thomson court, was consistent with this position because, although the case refused to give weight to an uncorroborated portion of an expert's affidavit, this was dictum, and, thus, not controlling precedent. $^{34}$

Additionally, Thomson disagreed that the corroboration rule was extended to include non-inventors in Woodland Trust. ${ }^{35}$ In Woodland Trust, ${ }^{36}$ the infringing defendant argued that the patent claims were invalid under 35 U.S.C. § 102(a), testifying that the claims had been anticipated by his prior invention and public use. ${ }^{37}$ According to Thomson, Woodland Trust properly applied the corroboration rule to the defendant's testimony because the defendant was a party to the litigation and claimed to be an inventor. $^{38}$

Finally, the Thomson court identified and summarized its unequivocal holding. Denying that the corroboration rule is necessary for uninterested parties, the court noted that patentees are protected from erroneous findings of invalidity by the clear and convincing standard of proof, in addition to numerous methods in the Federal Rules of Civil Procedure and Evidence by which a party may test, challenge, impeach, and rebut

${ }^{31}$ See Thomson, 166 F.3d at 1176 (citing Barbed-Wire, 143 U.S. at 284-85).

${ }^{32}$ See Thomson, 166 F.3d at 1176 (citing Barbed-Wire, 143 U.S. at 284-85).

${ }^{33}$ In re Reuter, 670 F.2d 1015 (C.C.P.A. 1981).

${ }^{34}$ Thomson, 166 F.3d at 1176 n.5.

${ }^{35} I d$. at 1176 n. 4 .

${ }^{36}$ Woodland Trust v. Flowertree Nursery, Inc., 148 F.3d 1368 (Fed. Cir. 1998).

${ }^{37}$ Thomson, 166 F.3d at 1176 n.4 (citing Woodland Trust, 148 F.3d at 1369-70).z

38 Id. (emphasis added) (citing Woodland Trust, 148 F.3d at 1369-70) (holding that the clear and convincing standard was not met after applying the corroboration rule, despite the testimony of four witnesses each related or long time friends of the defendant). 
oral testimony. ${ }^{39}$ Thus, according to the Thomson court, "the corroboration rule is needed only to counterbalance the self-interest of a testifying inventor against the patentee."40 Presumably to assure that its holding would not be mistaken as dictum, Thomson recited that " $[\mathrm{w}] \mathrm{e}$ therefore hold that corroboration is required only when the testifying inventor is asserting a claim of derivation or priority of his or her invention and is a named party, an employee of or assignor to a named party or otherwise is in a position where he or she stands to directly and substantially gain by his or her invention being found to have priority over the patent claims at issue." ${ }^{41}$ Nonetheless, some commentators have asserted that because these circumstances were not present in Thomson's facts, this pronouncement was arguably dictum for all future cases. ${ }^{42}$

Thus, if Thomson is limited only to its facts, the case teaches that the corroboration rule is not required for non-party inventors of a prior non-patented invention when the inventors' interest in the outcome of the litigation does not rise to a level that necessitates triggering the rule. ${ }^{43}$ Read more broadly, the language in Thomson only requires the application of the corroboration rule when "the testifying inventor [(1)] is asserting a claim of derivation or priority of his or her invention and [(2) the inventor] is a named party, an employee of or assignor to a named party, or otherwise in a position...to directly and substantially gain by his or her invention being found to have priority over the patent claims at issue."44

\footnotetext{
${ }^{39}$ Id.

${ }^{40} I d$.

${ }^{41} I d$. (emphasis added).

${ }^{42}$ See Charles L. Gholz, A Critique of Recent Opinions of the Federal Circuit in Patent Interferences, $82 \mathrm{~J}$. PAT. \& TRADEMARK OFF. SOC'Y 296, 300 (2000).

${ }^{43}$ Thomson, 166 F.3d at 1174-75.

${ }^{44} I d$. at 1176 (emphasis added).
} 
Either reading of the case pulls away from a bright-line application of the corroboration rule insofar as it gives complete discretion to the decision-maker to assess whether the witness's interest in the outcome of the litigation rises to a level that necessitates triggering the corroboration rule when the witness is not a named party, employee of, or assignor to a named party. ${ }^{45}$ However, the court maintains some semblance of rigidity by requiring the rule's application to inventors that are objectively interested in the litigation's outcome, namely, when the inventor is a named party, an employee of, or assignor to a named party and the inventor is asserting a claim of derivation or priority. ${ }^{46}$ The harshness of strictly applying this rule to inventors that are named parties, employees of, or assignors to named parties is mollified by the court's restricted application of the rule only to defendants asserting a claim of derivation or priority. ${ }^{47}$

B. Corroboration Required Irrespective of Interest or Inventorship Status: Finnigan Corp. v. ITC

Only four and a half months after Thomson, the Federal Circuit decided Finnigan, holding that the patent at issue was not invalid as anticipated under 35 U.S.C. $§$ 102(b), thereby reversing the International Trade Commission's ("Commission") prior determination that it was invalid. ${ }^{48}$ In the prior proceeding, the Commission adopted the recommendations of the Administration Law Judge ("ALJ") who found that the patent was anticipated based on a third party's, Jefferts, published article and testimony that he

${ }^{45} I d$, at $1174-76$.

${ }^{46} I d$.

${ }^{47} I d$. at 1176 .

${ }^{48}$ Finnigan, 180 F.3d at 1360, 1370. 
used the claimed invention. ${ }^{49}$ Responding to the patent owner's argument that Jefferts' testimony was insufficient absent other corroborating evidence, the ALJ dismissed the notion that Jefferts' credibility was at issue because he was not an interested party. ${ }^{50}$

However, the Federal Circuit reversed the Commission's finding of anticipation. ${ }^{51}$ While the Commission relied on Jefferts' testimony and article to corroborate one another, ${ }^{52}$ the Federal Circuit noted that the article did not sufficiently disclose the patented invention, and, thus, it did not anticipate the invention or corroborate Jefferts' testimony. ${ }^{53}$ Regarding Jefferts' testimony, the Federal Circuit determined that the testimony did not close the gaps in the article and, consequently, the testimony could not corroborate the article. ${ }^{54}$ Regarding whether Jefferts' testimony had to be corroborated, the Federal Circuit asserted that "corroboration is required of any witness whose testimony alone is asserted to invalidate a patent, regardless of his or her level of interest." 55 The court reasoned that the "law has long looked with disfavor" upon invalidating patents based merely on uncorroborated testimonial evidence, citing the Supreme Court's sentiments in Barbed-Wire Patent one hundred years earlier. ${ }^{56}$ Namely, according to Finnigan, the Supreme Court in that case expressed that such testimony rarely satisfies the clear and convincing standard due to "the forgetfulness of witnesses, their liability to mistakes, [and] their proneness to recollect things as the party calling them would have them recollect them.. ${ }^{, 57}$ Further, the Finnigan court explained that

${ }^{49} I d$. at $1360-61$.

${ }^{50} \mathrm{Id}$. at 1361 .

${ }^{51} I d$. at 1370

${ }^{52} I d$. at 1361.

${ }^{53} I d$. at $1366,1369$.

${ }^{54}$ Finnigan, 180 F.3d at 1366.

${ }^{55} \mathrm{Id}$. at 1369 .

${ }^{56} \mathrm{Id}$. at 1366.

${ }^{57}$ Id., (citing Barbed Wire Patent, 143 U.S. at 284.). 
courts should receive mere testimony concerning invalidating activities with skepticism because such activities are normally documented by tangible evidence. ${ }^{58}$ Thus, the court held that because Jefferts' testimony was not corroborated by any other evidence, it was insufficient as a matter of law to establish invalidity. ${ }^{59}$

Instead of giving deference to the Commission's decision regarding the credibility of Jefferts' testimony, the Finnigan court went another direction, requiring corroboration for any witness, interested or not, whose testimony alone is asserted to invalidate a patent. ${ }^{60}$ In addition to this bright-line rule, the Finnigan court also arguably extended its application, stating that while the corroboration rule has been applied the most under 35 U.S.C. $§ 102(\mathrm{~g})$, “[n]o principled reason appears for applying a different rule when other subsections of $\S 102$ are implicated."61 Thus, on its face, the Finnigan court erected significant barriers toward proving patent invalidity ${ }^{62}$-automatically applying the brightline corroboration rule to all witnesses ${ }^{63}$ and extending its application to all subsections of $\S 102 .^{64}$

C. Reuter Factors for the Testimony of More than One Witness

\footnotetext{
${ }^{58}$ Finnigan, 180 F.3d at 1366 . The Federal Circuit has stated that '[i]t is rare indeed that some physical record (e.g., a written document such as notes, letters, invoices, notebooks, or a sketch or drawing or photograph showing the device, a model, or some other contemporaneous record) does not exist' to corroborate the testimonial evidence. Finnigan, 180 F.3d at 1366-67 (citing Woodland Trust, 180 F.3d at 1373). Accord Eibel, 261 U.S. at 60.

${ }^{59} I d$. at 1369.

${ }^{60}$ See id. at 1369.

${ }^{61}$ See Finnigan, 180 F.3d at 1367. But see Norian, 252 F. Supp. 2d at 956 (reasoning that the Federal Circuit in Finnigan did not intend to extend the corroboration requirement to any and all elements within the subsections of section 102).

${ }^{62}$ See 3 Robert A. Matthews, Jr., Annotated Patent Digest § 17:32 (2006).

${ }^{63}$ See Finnigan, 180 F.3d at 1369.

${ }^{64} \mathrm{Id}$. at 1367 .
} 
When assessing whether testimonial or physical evidence corroborates another witness's testimonial evidence ${ }^{65}$ or, using the Finnigan court's terminology, during a sufficiency of corroboration analysis, ${ }^{66}$ an appellate court should take multiple factors into account. ${ }^{67}$ These factors, referred to as the Reuter factors or a "rule of reason" analysis, ${ }^{68}$ assist a court in evaluating the credibility of the witness's oral statements. ${ }^{69}$ The Reuter factors include: (1) the relationship between the corroborating witness and the alleged prior user, (2) the time period between the event and trial, (3) the interest of the corroborating witness in the subject matter in suit, (4) contradiction or impeachment of the witness's testimony, (5) the extent and details of the corroborating testimony, (6) the witness's familiarity with the subject matter of the patented invention and the prior use, (7) the probability that a prior use could occur considering the state of the art at the time, and (8) the impact of the invention on the industry and the commercial value of its practice. $^{70}$

Under a "rule of reason" analysis, an appellate court does not require that every aspect of an inventor's testimony be corroborated, but, rather, the court can determine the adequacy of corroboration on a case-by-case basis. ${ }^{71}$ The ultimate goal is for the trier-offact to implicitly make a credibility determination regarding whether the proffered

\footnotetext{
${ }^{65}$ See Ethicon, Inc. v. U.S. Surgical Corp., 135 F.3d 1456, 1461 (Fed. Cir. 1998) (“corroborating evidence may take many forms. Often, contemporaneous documents prepared by a putative inventor serve to corroborate an inventor's testimony. Circumstantial evidence about the inventive process may also corroborate. Additionally, oral testimony of someone other than the alleged inventor may corroborate.”).

${ }^{66}$ See Finnigan, 180 F.3d at 1369 n.11.

${ }^{67}$ See Price v. Symsek, 988 F.2d 1187, 1195 (Fed. Cir. 1993); In re Reuter, 670 F.2d 1015, 1021 \& n.9 (C.C.P.A. 1981).

${ }^{68}$ See Price, 988 F.2d at 1195.

${ }^{69}$ See In re Reuter, 670 F.2d at 1021 \& n.9.

${ }^{70}$ Woodland Trust, 148 F.3d at 1371 (citing Price, 988 F.2d at 1195 n.3).

${ }^{71}$ Coleman v. Dines, 754 F.2d 353, 360 (Fed. Cir. 1985); See, e.g., Cooper v. Goldfarb, 154 F.3d 1321, 1330 (Fed. Cir. 1998) ("[An] actual reduction to practice does not require corroboration for every factual issue contested by the parties."); Reese v. Hurtz, 661 F.2d 1222, 1225 (C.C.P.A. 1981) (“[T]his court, by adopting a 'rule of reason,' has eased the requirement of corroboration with respect to the evidence necessary to establish the credibility of the inventor.")..
} 
witness testimony or documents corroborate the challenged witness's testimony. ${ }^{72}$ Under Finnigan, however, witness testimony offered by itself is inherently unreliable when there is no other corroborating evidence, ${ }^{73}$ even when the witness's credibility has not been directly challenged.

\section{ANALYSIS}

The transparently conflicting holdings in Thomson and Finnigan may reflect Finnigan's attempt to overrule Thomson. However, because the Finnigan court was not sitting en banc $^{74}$ it did not have the authority to do so. ${ }^{75}$ The Thomson court unequivocally asserted that "corroboration is required only when the testifying inventor is asserting a claim of derivation or priority of his or her invention and is a named party, an employee of or assignor to a named party, or otherwise is in a position where he or she stands to directly and substantially gain by his or her invention being found to have priority over the patent claims at issue."76 Contrastingly, the Finnigan court emphatically stated that "corroboration is required of any witness whose testimony alone is asserted to invalidate a patent, regardless of his or her level of interest" as applied to all subsections under $§ 102 .^{77}$

\section{A. Inconsistent Positions by the Federal Circuit}

\footnotetext{
72 Engate, 331 F. Supp. 2d at 686.

${ }^{73}$ See Finnigan, 180 F.3d at 1369.

${ }^{74}$ See Nippon Steel Corp. v. United States, 458 F.3d 1345, 1350-51 n.3 (Fed. Cir. 2006) (relating that only a court sitting en banc may overrule a prior panel's decision).

${ }^{75}$ See Engate, 331 F. Supp. 2d at 684-85 (citing K \& K Jump Start/Chargers Inc. v. Schumacher Electric Corp., 82 F. Supp. 2d 1012, 1018 n.7 (W.D. Miss. 2000) (overruled on other grounds)) (reasoning that while Thomson has not been overruled, subsequent decisions suggest that its holding may not be viable). See also Norian, 252 F. Supp. 2d at 956 (reasoning that if Finnigan really does advocate an across-theboard corroboration rule, it "would be hard to reconcile" with Thomson and Carella).

${ }^{76}$ Thomson, 166 F.3d at 1176 (emphasis added).

${ }^{77}$ Finnigan, 180 F.3d at 1367, 1369 (emphasis added).
} 
The Finnigan court's veiled attempt to overrule Thomson is reflected by a sideby-side comparison of the two cases' contradictory holdings and rationales, the effects of which have caused confusion in the district courts regarding the legal standard for uninterested witness corroboration. ${ }^{78}$ Finnigan's attempt to reconcile Thomson creates a false distinction that disregards and ultimately contradicts Thomson's unambiguous holding. By asserting that a bright-line rule for corroboration is and always has been required irrespective of interest, Finnigan ignores that past cases, such as Thomson, have taken a seemingly different approach. Indeed, the reasoning underlying the holdings in the two cases use inconsistent interpretations of the same case precedent to support their polar positions, which has also likely contributed to the confusion regarding the state of the law on this issue.

\section{Finnigan's Unsuccessful Attempt to Reconcile Thomson}

Finnigan's attempt to reconcile Thomson fails to square multiple aspects of the Thomson decision itself. In Finnigan, the court attempted to reconcile Thomson by categorizing the Thomson court's reasoning as a sufficiency of corroboration analysis, as opposed to whether the Thomson court was considering the necessity of corroboration vel non. ${ }^{79}$ To do this, the Finnigan court highlighted the fact that Thomson involved multiple sources of evidence, including the testimony of the two employees; an expert's report,

\footnotetext{
${ }^{78}$ See, e.g., Engate, 331 F. Supp. 2d at 684 (expressing confusion over the "intra-circuit split" regarding whether the corroboration requirement applies to disinterested non-parties); Norian, 252 F. Supp. 2d at 955-56 (reasoning that the Federal Circuit in Finnigan did not intend to extend the corroboration requirement to any and all elements within the subsections of section 102); $K \&$ K Jump Start/Chargers, 82 F. Supp. 2d at 1018 n.7 (following Finnigan because it is the "safe[st] option"); Briton v. Loggans, 2006 WL 2336556, No. 3:04-0177, at *2 (M.D. Tenn. 2006) (same).

${ }^{79}$ Finnigan, 180 F.3d at 1368.
} 
exhibits, and documents that he reviewed; and portions of his deposition testimony. ${ }^{80}$ Generally, an analysis to determine whether there is sufficient corroborating evidence is a totality of the circumstances assessment that evaluates and weighs the Reuter factors, including whether the witnesses are interested. ${ }^{81}$ Because Thomson involved multiple sources of evidence, according to Finnigan, the Thomson court took into account the fact that the witnesses were disinterested under a sufficiency of evidence analysis. ${ }^{82}$ In contrast, according to the Finnigan court, because Finnigan only involved the uncorroborated testimony of a single witness, the Finnigan court only needed to address the necessity of corroboration rather than the sufficiency of the corroborating evidence. ${ }^{83}$

On its face, Finnigan's explanation of Thomson contradicts the opinion's language and facts in the Thomson opinion itself. First, the Thomson court's language, such as "neither the Supreme Court nor we have directly held whether the corroboration rule must be applied to testimony by non-party inventors," "the corroboration rule is needed only to counterbalance the self-interest of a testifying inventor," and "corroboration is required only when the testifying inventor is . . a named party," ${ }^{, 84}$ goes to necessity, rather than sufficiency, of corroboration.

Second, Finnigan distinguishes Thomson on the fact that the finding of anticipation was based on multiple sources of evidence in addition to the witnesses' testimony; ${ }^{85}$ however, the Thomson court noted that this finding "came from one or more sources." $" 86$ Thus, by including "one" in this statement, the Thomson court foreclosed this

\footnotetext{
${ }^{80} I d$.

${ }^{81} I d$. at 1369.

${ }^{82} \mathrm{Id}$.

${ }^{83} I d$. at 1368.

${ }^{84}$ Thomson, 166 F.3d at 1176.

${ }^{85}$ Finnigan, 180 F.3d at 1368.

${ }^{86}$ Thomson, 166 F.3d at 1174.
} 
distinction. Furthermore, the Thomson court explicitly conceded this point, ${ }^{87}$ stating that “[e]ven if we accept Thomson's first assertion [that the jury verdict rested solely on the testimony of the two former non-party MCA employees], and further assume that the MCA employees were acting as inventors in the laser videodisc project, Thomson's argument fails because this case does not present circumstances in which there is a need for corroboration....,"88

Finally, assuming arguendo that Thomson did involve a sufficiency of corroboration analysis, neither the reasoning or the holding in Thomson refer to any other evidence besides the witnesses' testimony nor does the discussion mention whether one witness's testimony corroborated the other's. Instead, the court treats their testimony aggregately, noting that their self-interest "does not . . . justify triggering application of the corroboration rule" and holding that "the testimony .. . did not have to be corroborated...., .,89

Additionally, the district court's decision, ${ }^{90}$ which the Federal Circuit in Thomson affirmed, is not contrary to this analysis. In the district court case, the plaintiff asserted, in support for its motion for a new trial, that the court erred in the jury trial by refusing to charge that corroboration was required for the two witnesses' oral testimony. ${ }^{91}$ In response, the district court stated that it refused to charge the jury that corroboration was required because "[t]he law is clear": "[t]he Federal Circuit has consistently held that only an inventor's testimony needs to be corroborated." 92 Thus, because "[i]t [was]

\footnotetext{
${ }^{87}$ Accord Hird, supra note 7, at 271.

${ }^{88}$ Thomson, 166 F.3d at 1174-75.

${ }^{89} \mathrm{Id}$. at 1176.

90 Thomson S.A. v. Quixote Corp., 979 F. Supp. 286 (D. Del. 1997).

${ }^{91} I d$. at 299.

92 Id. at 299, (citing Price v. Symsek, 988 F.2d 1187, 1195 ("Only the inventor's testimony requires corroboration before it can be considered”); Holmwood v. Sugavanam, 948 F.2d 1236, 1239 (Fed. Cir.
} 
undisputed that" the witnesses here were not inventors, the district court did not require corroboration of their testimony. ${ }^{93}$ Although the Federal Circuit later amended this reasoning by assuming that the witnesses were inventors, ${ }^{94}$ the Federal Circuit's holding was founded on the lack of the inventors' self-interest, ${ }^{95}$ rather than the absent and later imposed rationale that one witness's testimony corroborated the other's.

\section{Contradictory Interpretations of the Same Case Precedent}

Both Thomson and Finnigan use different interpretations of the same Federal Circuit and Supreme Court precedent, Woodland Trust and the Barbed-Wire Patent, to support irreconcilable holdings.

\section{a. Woodland Trust}

In Woodland Trust, the defendant claimed to be a prior inventor, but the Federal Circuit held that the evidence did not meet the clear and convincing standard necessary to show anticipation, despite the testimony of four witnesses that were all related to the defendant by blood or long friendship. ${ }^{96}$ In Thomson, the court recognized that the Federal Circuit in Woodland Trust held that an inventor's testimony alone cannot satisfy the clear and convincing standard without corroboration. ${ }^{97}$ However, the Thomson court asserted that the Federal Circuit properly applied the corroboration rule in that case

1991) (“Only an inventor's testimony needs corroboration”); Borror v. Herz, 666 F.2d 569, 573 (C.C.P.A. 1981) ("The testimony of witnesses, other than the inventor, is not ipso facto of a subordinate nature. On the contrary, it is only the inventor's testimony that cannot stand alone.")).

93 Thomson, 979 F. Supp. at 299.

${ }^{94}$ Thomson, 166 F.3d at 1174-75.

${ }^{95} \mathrm{Id}$. at 1176.

${ }^{96}$ Woodland Trust, 148 F.3d at 1369-71.

${ }^{97}$ Thomson, 166 F.3d at 1175, (citing Woodland Trust, 148 F.3d at 1371). 
because it involved a defendant that "was a party who claimed to be an inventor." 98 Accordingly, the Thomson court noted that Woodland Trust and other decisions like it did not require courts to automatically apply the corroboration rule to testimony by non-party inventors,${ }^{99}$ but rather it was up to the court's discretion to apply the rule to non-party, non-interested inventors.

In comparison, the Finnigan court recast Woodland Trust as a case that considered the defendant's level of interest as an inventor only because the court was evaluating whether there was sufficient evidence to corroborate the witness's testimony. ${ }^{100}$ According to Finnigan, Woodland Trust did not stand for the proposition that only an interested witness's testimony requires corroboration, ${ }^{101}$ but rather that corroboration is required for non-party, non-interested inventors as well.

\section{b. Barbed-Wire Patent}

The Thomson and Finnigan courts' use of the Barbed-Wire Patent is even more divergent. In the Barbed-Wire Patent, twenty-four witnesses testified that they observed the invention at issue, a barbed wire fence, in prior public use. ${ }^{102}$ However, the Supreme Court held that the combined testimony was insufficient to establish invalidity based on a multitude of considerations. ${ }^{103}$ First, the Court noted that there was very little evidence to show that any of the allegedly anticipating devices were constructed according to the

\footnotetext{
${ }^{98}$ Id. at 1175 n.4 (emphasis in original), (citing Woodland Trust, 148 F.3d at 1369-70).

${ }^{99}$ Thomson, 166 F.3d at 1176.

${ }^{100}$ Finnigan, 180 F.3d at 1369 .

${ }^{101} I d$.

${ }^{102}$ Barbed Wire, 143 U.S. at 287.

${ }^{103}$ Id. at $289-292$.
} 
design of the patent at issue. ${ }^{104}$ Second, referencing that twenty-five years had elapsed since the alleged public use, the Court reasoned it would be highly improbable that any witness that saw the anticipating fence for the single day it was exhibited would be able to describe it accurately. ${ }^{105}$ Third, the fact that all or nearly all of the allegedly anticipating experiments had been abandoned or lost demonstrated that the alleged prior inventor and the public viewed the invention as having no practical value. ${ }^{106}$ Finally, in reaching its holding, the Court noted that significant portions of the defendants' testimony were either contradictory on their own, negated by witness testimony put forth by the plaintiff, or highly improbable. ${ }^{107}$

In Thomson, the court argued that cases that discuss skepticism toward uncorroborated inventor testimony involve situations where inventors are self-interested in the litigation and, as a result, tempted to "remember" facts favorable to their case. ${ }^{108}$ The court in Thomson noted that in the Barbed-Wire Patent, the court in that case required corroboration of the twenty-four witnesses' testimony because the "testifying non-party inventors' patents would increase in value if [the] patent claims at issue were invalidated."109 Conversely, the Finnigan court cited the Barbed-Wire Patent as standing for the principle that uninterested witnesses are also subject to the corroboration requirement because the Supreme Court required corroboration of the twenty-four witnesses' testimony, even though they were "all apparently uninterested."110

\footnotetext{
${ }^{104} \mathrm{Id}$. at 289.

${ }^{105} \mathrm{Id}$.

${ }^{106}$ See id.

${ }^{107}$ See id. at 287-92.

${ }^{108}$ Thomson, 166 F.3d at 1176 (citing Barbed Wire, 143 U.S. at 284-85).

${ }^{109} I d$.

${ }^{110}$ Finnigan, 180 F.3d at 1367-68 (citing Barbed Wire, 143 U.S. at 286-87).
} 
In spite of both interpretations, the Barbed-Wire Patent decision itself did not reference the term "corroboration," but rather the decision took into account a multitude of considerations--none of which included interest--to determine that the witnesses' testimony was insufficient to establish anticipation. ${ }^{111}$ Thus, similar to Woodland Trust, Barbed-Wire Patent does not support Finnigan's extreme bright-line rule for uninterested witness corroboration because the Court did not address this. Instead, the Court used its discretion to evaluate and weigh the witness's testimony, substantively employing some of the Reuter factors, such as the time period between the event and trial, to determine that the defendant did not meet the burden for proving patent invalidity. ${ }^{112}$

\section{Still Confusion After Finnigan}

Not surprisingly, after Finnigan and Thomson there is confusion in the district courts regarding the status of the law for single witness corroboration. For example, in Engate, the district court expressed confusion over the "intra-circuit split" in the Federal Circuit regarding whether the corroboration requirement applies to disinterested nonparties in light of the two apparently contradictory cases, Thomson and Finnigan. ${ }^{113}$ After a discussion that favored overruling Finnigan, the Engate court concluded that it was not prepared to disregard Finnigan and that subsequent cases have relied on the

case's understanding of the corroboration requirement. ${ }^{114}$ Nonetheless, the Engate court noted that "[o]ne can only hope that the Federal Circuit will resolve the conflict created

\footnotetext{
111 See Barbed Wire, 143 U.S. at 292.

112 See id. at 287-92.

113 Engate, 331 F. Supp. 2d at 684.

${ }^{114}$ Id. at 684-85.
} 
by its decisions on this issue." 115 Another trend in the district courts may be for the factfinder to implicitly determine that the single witness's testimony is credible and hold accordingly, without explanation or reference to this convoluted area of the law. ${ }^{116}$ Similarly, another aspect of Finnigan has been called into question, namely, whether the Finnigan court intended to extend the bright-line corroboration requirement to any and all subsections of $\S 102 .{ }^{117}$ Because witness testimony is such a significant aspect of invalidity cases, the incongruity in the case law and resultant discord in the district courts is alarming and should be properly addressed by the Federal Circuit.

\section{B. Realigning the Corroboration Standard with Precedent and Policy}

In light of the irreconcilable holdings and rationales in Thomson and Finnigan, and the resulting confusion in the district courts, the current standard for uninterested, non-party, single witness testimony should be realigned with precedent and policy. The Federal Circuit should adopt or revert to a more moderate requirement for single witness corroboration, as laid out in Thomson, in lieu of the bright-line rule set forth in Finnigan. This recommendation is supported by the language, rationales, and application of the corroboration rule in case precedent, in addition to policy considerations, that heavily weigh against a bright-line rule. Additionally, the Federal Circuit may supplement or alternatively replace this more moderate standard for the corroboration of single witness

\footnotetext{
${ }^{115}$ Id. at 685. See also $K \&$ \& Jump Start/Chargers, 82 F. Supp. 2d at 1018 n.7 (noting that following Finnigan is the "safe[st] option"); Briton v. Loggans, 2006 WL 2336556 at *3 (citing Engate, 331 F. Supp. $2 \mathrm{~d}$ at 685 that the " 'safe[st]' option is 'to operate under the assumption that the corroboration requirement still exists." ).

${ }^{116}$ See, e.g., R.H. Murphy Co. V. Ill. Tool Works, Inc., 409 F. Supp. 2d 53, 73 n.54 (D. Mass. 2006).

117 See Norian, 252 F. Supp. 2d at 955 (reasoning that the Federal Circuit in Finnigan did not intend to extend the corroboration requirement to any and all elements within the subsections of $\S 102$ ). $C f$. Finnigan, 180 F.3d at 1367 (stating that while the corroboration rule has been applied the most under 35 U.S.C. $\S 102(\mathrm{~g})$, “[n]o principled reason appears for applying a different rule when other subsections of $\S$ 102 are implicated...").
} 
testimony with the Reuter factors, which the court currently employs when there is more than one witness testifying.

\section{Implementing a More Moderate Standard in Lieu of a Bright-Line Rule}

The Thomson decision embodies a middle-of-the-road position: the corroboration rule is not required for non-interested inventors, but it is required for interested inventors asserting a claim of derivation or priority. ${ }^{118}$ The underside of this position is that, in some cases, courts should apply the corroboration rule to non-interested inventors, but it is not required. In all other cases involving non-interested, non-inventors, the credibility of the witness testimony is left up to the factfinder's discretion.

In contrast, Finnigan's bright-line rule overprotects patent rights by unnecessarily taking the application of the corroboration rule to an extreme position. Under Finnigan, the testimony of one interested witness can corroborate an inventor's, or other interested witness's, testimony. ${ }^{119}$ However, the testimony of one disinterested witness may arguably be vastly more reliable than the testimony of an inventor corroborated by an interested witness's bare statements, yet the Federal Circuit takes the discretion away from the factfinder in the first case, ${ }^{120}$ but allows it in the second. ${ }^{121}$ Furthermore, also

\footnotetext{
${ }^{118}$ Thomson, 166 F.3d at 1176.

119 See Engate, 331 F. Supp. 2d at 685-86 (citing Woodland Trust v. Flowertree Nusery, 148 F.3d 1368, 1371 (Fed. Cir. 1998) (noting that the Federal Circuit had implicitly accepted that testimonial evidence can satisfy the corroboration requirement under certain circumstances).

${ }^{120}$ Finnigan Corp. v. ITC, 180 F.3d 1354 (Fed. Cir. 1999).

${ }^{121}$ See, e.g., Trovan, Ltd. V. Sokymat SA, Irori, 299 F.3d 1292, 1303 (Fed. Cir. 2002); Cooper v. Goldfarb, 154 F.3d 1321, 1330 (Fed. Cir. 1998) (evaluation of circumstantial evidence was sufficient corroboration); Holmwood v. Sugavanam, et al., 948 F.2d 1236, 1239 (Fed. Cir. 1991) (testimony of a witness affiliated with the inventor's corporation was sufficient corroboration); Lacotte v. Thomas, 758 F.2d 611, 613 (Fed. Cir. 1985) (a research associate's testimony sufficiently corroborated an inventor's testimony and notebook); Bennett v. Serota, 477 F.2d 1385, 1391 (C.C.P.A. 1973) (testimony of an inventor's assistant was sufficient corroboration). But see, e.g., Woodland Trust v. Flowertree Nusery, 148 F.3d 1368, 1371-73 (Fed. Cir. 1998) (holding that oral testimony of interested witnesses was insufficient corroboration); Hahn v. Wong, 892 F.2d 1028, 1032-33 (Fed. Cir. 1989) (noting that the inventor must provide corroborating evidence independent of information received from the inventor).
} 
consistent with Finnigan, both evidence that is under the inventor's sole control ${ }^{122}$ and testimony by family members of an inventor ${ }^{123}$ can potentially corroborate the inventor's testimony. The Federal Circuit's allowance of these types of corroborating evidence to be considered by the factfinder, but its removal of an uninterested witness's testimony from the factfinder's consideration, disproportionately protects patent rights. Surely, giving the factfinder discretion to decide whether an inventor's testimony is corroborated by a family member's ${ }^{124}$ is no more difficult than allowing the factfinder to decide the credibility of a single uninterested witness's testimony.

\footnotetext{
${ }^{122}$ See, e.g., Sandt Tech., Ltd. v. Resco Metal \& Plastics Corp., 264 F.3d 1344, 1351-52 (Fed. Cir. 2001); Ethicon, Inc. v. United States Surgical Corp., 135 F.3d 1456, 1464 (Fed. Cir. 1998) ; Anderson v. Pieper, 442 F.2d 982, 985 (C.C.P.A. 1971) (holding that the rule of reason indicated that notebook entries, authenticated by persons who did not personally observe the tests recorded therein, sufficiently corroborated evidence of the inventor's testimony); Berry v. Webb, 412 F.2d 261, 267-68 (C.C.P.A. 1969) (holding that the inventor's notebook and his lab partner's observation of the experiment was sufficient corroboration); Ritter v. Rohm \& Haas Co., 271 F. Supp. 313, 320 (S.D.N.Y. 1967) (“[I]t would be absurd to hold that Ritter's notebook is not sufficient corroboration. ... It is hard to imagine what more reliable corroborative evidence could be found .... To rule out Ritter's notebook on the ground that it is 'self serving' is to exalt labels over reason.”). But see Brown v. Barbacid, 276 F.3d 1327, 1335 (Fed. Cir. 2002) ("The Board did not err in holding that an inventor's own unwitnessed documentation does not corroborate an inventor's testimony about inventive facts."); Thurston v. Wulff, 164 F.2d 612, 617 (C.C.P.A. 1947) ("An inventor's testimony, however, might be corroborated by facts and circumstances other than by an independent witness. Such proof or evidence should be independent of the testimony of the inventor and should not consist of self-serving documents prepared by him or under his direction, nor should it be based upon facts the truth of which depends upon information received from the inventor."). Cf. Reese v. Hurst, 661 F.2d 1222, 1240 (C.C.P.A. 1981) (holding Thurston to be "inconsistent" with the rule of reason).

${ }^{123}$ See, e.g., Oney v. Ratliff, 182 F.3d 893, 897 (Fed. Cir. 1999) (rejecting patentee's argument that uncorroborated testimony of the challenger/inventor that was only supported by other oral testimony of two family members and a close friend could not support a verdict of invalidity in view of other evidence that raised fact issues relating to the on-sale activity and the applicability of Woodland); Ellis v. Maddox, 96 F.2d 308, 314(C.C.P.A. 1938) (same); Greenawalt v. Dwight, 258 F. 982, 983 (App. D.C. 1919) (holding the testimony of two brothers to be sufficient corroboration); Williams v. Shireffs, 1922 C.D. 41, 44 ("Although the corroborating testimony of relatives is relied upon, yet there is no impropriety in this, only their testimony must be carefully scrutinized.").

${ }^{124}$ See, e.g., Oney v. Ratliff, 182 F.3d 893, 897 (Fed. Cir. 1999) (rejecting patentee's argument that uncorroborated testimony of the challenger/inventor that was only supported by other oral testimony of two family members and a close friend could not support a verdict of invalidity in view of other evidence that raised fact issues relating to the on-sale activity and the applicability of Woodland); Ellis v. Maddox, 96 F.2d 308, 314(C.C.P.A. 1938) (same); Greenawalt v. Dwight, 258 F. 982, 983 (App. D.C. 1919) (holding the testimony of two brothers to be sufficient corroboration); Williams v. Shireffs, 1922 C.D. 41, 44 ("Although the corroborating testimony of relatives is relied upon, yet there is no impropriety in this, only their testimony must be carefully scrutinized.").
} 
Additionally, the rationale underlying this bright-line rule, namely, the inherent unreliability of a single witness's testimony to in and of itself invalidate a patent, is paradoxical in practice. If one party's testimony is inherently unreliable irrespective of interest, it is puzzling why a second party's testimony is reliable enough to automatically permit the evidence to go to the factfinder. This arbitrary line, drawn by the Finnigan court, takes the discretion away from the factfinder when only one witness is present, but reinstates it for two witnesses. This inconsistency was also observed by the Engate court, noting that this construction of the corroboration requirement demonstrates that the rule has "seen better days and ought to be put out of its misery humanely rather than being forced to suffer the death of a thousand cuts" because "evidently the whole is greater than the sum of its parts." 125

\section{Rationale and Application of the Corroboration Rule in Case Precedent}

The bright-line solution in Finnigan also undermines the purpose of the corroboration requirement and its application in case precedent. The underlying purpose of the corroboration requirement for witness testimony was "to prevent fraud, by providing independent confirmation of the inventor's testimony." ${ }^{26}$ Based on this rationale, the inference is that non-inventor or otherwise uninterested witness's testimony was distinguishable and outside the scope of the corroboration rule, which is consistent with the standard that Thomson advocated. Nonetheless, the scope of the rule has been broadened into a full-fledged, bright-line application to both interested and disinterested

\footnotetext{
${ }^{125}$ Engage, Inc. v. Esquire Deposition Serv., 331 F.Supp.2d 673, 686.n4 (N.D.Ill. 2004).

${ }^{126}$ Kridl v. McCormick, 105 F.3d 1446, 1450 (Fed. Cir. 1997); Berry, 412 F.2d at 267 ("The purpose of the rule requiring corroboration is to prevent fraud.").
} 
parties alike. ${ }^{127}$ If uninterested parties do require corroboration, this contradicts the standard in place that expert testimony does not require it. ${ }^{128}$ Additionally, this strict version of the corroboration rule overlaps with established protections, such as the clear and convincing standard of proof and the Federal Rules of Civil Procedure and Evidence, that buffer against erroneous findings of invalidity. ${ }^{129}$ Thus, the use of a bright-line corroboration rule in addition to well-established protections not only disproportionately favors the patentee, but also renders the latter superfluous.

Indeed, an overwhelming number of Federal Circuit cases and cases from its predecessor court qualify the corroboration requirement as applying specifically to inventors or other interested parties, which cuts away from Finnigan's all-inclusive scope. ${ }^{130}$ For example, in Lacks, citing the Barbed-Wire Patent and Union Carbide, the court stated that "[a] review of the relevant case law reveals a clear requirement that such oral testimony by interested parties must be corroborated by documentary testimony.",131

\footnotetext{
${ }^{127}$ See generally Finnigan Corp. v. ITC, 180 F.3d 1354 (Fed. Cir. 1999).

${ }^{128}$ In re Reuter, 670 F.2d 1015, 1021 (C.C.P.A. 1981) ("As to corroboration, the statement of an expert's opinion set forth in an affidavit need not be corroborated. However, corroboration may be necessary for other statements.").

${ }^{129}$ See Thomson v. Quixote Corp., 166 F.3d 1172, 1176 (Fed. Cir. 1999).

${ }^{130}$ See, e.g., Clark Thread Co. v. Willimantic Linen Co., 140 U.S. 481, 489 (1891) (inventor's testimony "is necessarily subject to the gravest suspicion, however honest and well intentioned the witness may be."); Singh v. Brake, 222 F.3d 1362, 1367 (Fed. Cir. 2000) ("The corroboration rule addresses the concern that a party claiming inventorship might be tempted to describe his actions in an unjustifiably self-serving manner in order to obtain a patent or to maintain an existing patent.”); Sandt Tech., Ltd. v. Resco Metal \& Plastics Corp., 264 F.3d 1344, 1350 (Fed. Cir. 2001) (same); Price v. Symsek, 988 F.2d 1187, 1195 (Fed. Cir. 1993) (noting tribunal must make a reasonable analysis of all pertinent evidence to determine whether the inventor's testimony is credible); Holmwood v. Sugavanam, 948 F.2d 1236, 1239 (Fed. Cir. 1991) ("Only an inventor's testimony needs corroboration"); Reese v. Hurst, 661 F.2d 1222, 1225 (C.C.P.A. 1981) ("Evidence of corroboration must not depend solely on the inventor himself."); Borror v. Herz, 666 F.2d 569, 573 (C.C.P.A. 1981) ("The testimony of witnesses, other than the inventor, is not ipso facto of a subordinate nature. On the contrary, it is only the inventor's testimony that cannot stand alone."); Berges v. Gottstein, 618 F.2d 771 (C.C.P.A. 1980); Stevenson v. Int'1 Trade Comm'n, 612 F.2d 546, 550 (C.C.P.A. 1979) ("Uncorroborated oral testimony of prior inventors or users with a demonstrated financial interest in the outcome of the litigation is insufficient to provide such proof.").

${ }^{131}$ Lacks Indus. v. McKechnie Vehicle Components USA, Inc., 322 F.3d 1335, 1350 (Fed. Cir. 2003) (citing Barbed Wire); Union Carbide v. Shell Oil Co., 308 F.3d 1167, 1189 (Fed. Cir. 2002)
} 
Similarly, even the Reuter factors or a "rule of reason" analysis that, according to Finnigan, the court should employ during a sufficiency of corroboration evaluation, was initially applied to corroborate an inventor's testimony. ${ }^{132}$

Furthermore, the case law does not support the unequivocal language that Finnigan invokes. Although the Finnigan court cites the Barbed-Wire Patent, the language in the Barbed-Wire Patent does not lend itself to an all or nothing rule. ${ }^{133}$ For example, the Supreme Court asserts that "witnesses whose memories are prodded by the eagerness of interested parties to elicit testimony favorable to themselves are not usually to be depended on for accurate information." ${ }^{134}$ Finnigan cites case precedent to support the tenet that witness testimony is "open to grave suspicion." 135 However, these statements do not reflect that witness testimony should be altogether disregarded and removed from the factfinder's discretion, but rather that it should be evaluated with caution.

Regarding Finnigan's apparent extension of the corroboration rule to all subsections of $\S 102$, Finnigan asserted that "[n]o principled reason appears for applying a different rule when other sections of $\S 102$ are implicated: a witness's uncorroborated testimony is equally suspect as clear and convincing evidence if he testifies concerning the use of the invention in public before invention by the patentee $(\S 102(a))$, use of the invention in public one year before the patentee filed his patent $(\S 102(b))$ or invention

(" $[\mathrm{u}]$ ncorroborated oral testimony by interested parties is insufficient as a matter of law to establish invalidity of [a] patent")).

${ }^{132}$ See Price, 988 F.2d at 1195 (“A 'rule of reason' analysis is applied to determine whether the inventor's prior conception testimony has been corroborated. An evaluation of all pertinent evidence must be made so that a sound determination of the credibility of the inventor's story may be reached."); Kridl v. McCormick, 105 F.3d 1446, 1449 (Fed. Cir. 1997).

${ }_{133}^{133}$ See generally Barbed Wire, 143 U.S. 275.

${ }^{134} I d$. at 284.

${ }^{135}$ Deering v. Winona Harvester Works, 155 U.S. 286, 300-01 (1894). 
before the patentee $(\S 102(\mathrm{~g})) . " 136$ Prior to Finnigan, however, the Federal Circuit required corroboration most often in the context of priority disputes under $\S \S 102(\mathrm{~g})^{137}$ and (f). ${ }^{138}$ In the context of $\S \S 102(\mathrm{~g})$ (priority) and (f) (derivation), the Federal Circuit has noted that "the case law is unequivocal that an inventor's testimony respecting facts surrounding a claim of derivation or priority of invention cannot, standing alone, rise to the level of clear and convincing proof." ${ }^{\prime 39}$ Although the Federal Circuit has required corroboration under other subsections, ${ }^{140}$ this does not necessitate an automatic extension of the corroboration rule to all subsections of $\S 102$.

Rather, the use of the corroboration rule in these cases exemplifies courts' abilities to function within their discretion to determine whether corroboration is needed on a case-by-case basis, without the restraints or pressures of a bright-line rule. Furthermore, these courts were not necessarily applying the corroboration rule, but rather acting as factfinders to determine the credibility of witnesses. ${ }^{141}$ It can be argued that the extensive use of the term "inventor" in case precedent ${ }^{142}$ coupled with the fact that courts

\footnotetext{
${ }^{136}$ Finnigan Corp. v. ITC, 180 F.3d 1354, 1367 (Fed. Cir. 1999).

${ }^{137}$ Id.; Mahurkar v. C.R. Bard, Inc., 79 F.3d 1572, 1577 (Fed. Cir. 1996). See, e.g., Thomson v. Quixote Corp., 166 F.3d 1172, 1174-75 (Fed. Cir. 1999); Cooper v. Goldfarb, 154 F.3d 1321, 1330 (Fed. Cir. 1998) ("In order to establish an actual reduction to practice, an inventor's testimony must be corroborated by independent evidence."); Coleman v. Dines, 754 F.2d 353, 359 ("Conception must be proved by corroborating evidence which shows that the inventor disclosed to others his "complete though expressed in such clear terms as to enable those skilled in the art' to make the invention.").

${ }^{138}$ See Lacks Indus. v. McKechnie Vehicle Components USA, Inc., 322 F.3d 1335, 1349 (Fed. Cir. 2003); Price v. Symsek, 988 F.2d 1187, 1194 (Fed. Cir. 1993). See, e.g., C.R. Bard, Inc. v. M3 Sys., Inc., 157 F.3d 1340, 1353 (Fed. Cir. 1998) (concluding that mere testimony of a purported inventor asserting invalidity for incorrect inventorship was insufficient to anticipate under $\S 102(f)$ ).

${ }^{139}$ Price, 988 F.2d at 1194.

${ }^{140}$ See Finnigan, 180 F.3d at 1367; see, e.g., Deering, 155 U.S. at 300-01 (concluding that mere testimony relevant to the invention's prior public use was insufficient to anticipate under the precursor to $\S 102(\mathrm{~b})$ ); Woodland Trust, 148 F.3d at 1373 (concluding that mere testimony relevant to the inventions' prior knowledge and use was insufficient to anticipate under $\S 102(a)$ ).

141 See Mahurkar v. C.R. Bard, Inc., 79 F.3d 1572, 1577 (Fed. Cir. 1996) (noting that the bright-line corroboration rule is "prophylactic in application given the unique abilities of trial court judges and juries to assess credibility.").

${ }^{142}$ See supra Part IIIB2.
} 
have applied the corroboration rule most extensively to $\S \S 102(\mathrm{f})$ and $(\mathrm{g})^{143}$ may indicate that the strict corroboration requirement was tailored exclusively for these two subsections. Unlike other subsections, both $\S \S 102(\mathrm{f})$ and (g) involve invalidity that exclusively involves the inventor. ${ }^{144}$

Furthermore, $\S \S 102(\mathrm{f})$ and $(\mathrm{g})$ are much more amenable to a bright-line corroboration rule because the circumstances consistently involve invention, whereas the circumstances involved in $\S \S 102(a)$ and (b), for example, are highly variable. ${ }^{145}$ As a result, rationales in case precedent that may support a strict version of the corroboration rule, such as to prevent fraud by independent confirmation of the inventor's testimony, ${ }^{146}$ only make sense as applied to $\S \S 102(\mathrm{f})$ and (g). Thus, if courts must apply it, the brightline rule rejecting a single witness's uncorroborated testimony is a poor fit outside of $\S \S$ 102(f) and (g), ${ }^{147}$ and, for other subsections, the Thomson standard is more contoured to the breadth of circumstances that may legitimately arise.

\section{Policy Considerations Weigh Against a Bright-Line Rule}

The necessity and underlying policy of a special corroboration rule for patent invalidity is not easy to understand, ${ }^{148}$ and it ultimately reflects social disutility. Under Finnigan, witness testimony offered to invalidate a patent can never meet the clear and

\footnotetext{
143 See Lacks, 322 F.3d 1349; Price, 988 F.2d at 1194.

${ }^{144}$ See 35 U.S.C. $\$ 102$.

${ }^{145}$ For example, third parties observing anticipating activities under $\S 102$ (b) are far less likely to have physical evidence of this occurrence than an inventor constructing and testing his invention. Accord Hird, supra note 5, at 282.

${ }^{146}$ Kridl, 105 F.3d at 1450.

${ }^{147}$ Accord Hird, supra note 5, at 282.

${ }^{148}$ Accord Engate, 331 F. Supp. 2d at 685.
} 
convincing evidentiary standard without corroboration. ${ }^{149}$ Although Thomson allowed the factfinder traditional deference to evaluate witness credibility without corroboration in certain circumstances, ${ }^{150}$ Finnigan effectively rejected this standard and extended the requirement to all testimony offered to invalidate a patent. ${ }^{151}$ Notably, it is almost unparalled in any other area of law for a factfinder to be directed, as a matter of law, to refuse to consider the testimony of a credible witness that may be sufficient to satisfy the evidentiary burden. ${ }^{152}$ Only two other areas of law have a comparably strict requirement for the corroboration of witness testimony. ${ }^{153}$ These include treason, which requires that one witness's testimony is always insufficient to meet the burden of proof as required by the Constitution, ${ }^{154}$ and the federal perjury statute, which used to have a two-witness rule. $^{155}$ The social utility of elevating the corroboration standard for patent invalidity to that of treason and federal perjury hardly seems congruent. Additionally, the Federal Circuit appears to be overstepping its boundaries in another regard, by usurping a role that is expressly reserved for the trial courts, namely, determining the weight of the evidence and credibility of the witnesses. ${ }^{156}$

Advocates of a bright-line rule for corroboration may assert that this special rule facilitates and maintains a high evidentiary standard of proof for clear and convincing evidence, but this argument fails relative to other areas of the law. Generally, the

\footnotetext{
${ }^{149}$ Finnigan, 180 F.3d at 1367. Accord Hird, supra note 5, at 258.

${ }^{150}$ See supra Part II.A.

${ }^{151}$ See supra Part II.B.

${ }^{152}$ Engate, 331 F. Supp. 2d at 684-85. See Hird, supra note 5, at 271.

${ }^{153}$ Engate, 331 F. Supp. 2d at 684-85.

${ }^{154}$ U.S. Const. art. III, $\S 3$.

${ }^{155}$ Engate, 331 F. Supp. 2d at 684-85.

${ }^{156}$ Hird, supra note 7, at 283. The Finnigan line of cases evidences a rare example of an appellate body independently weighing the evidence and considering the credibility of the witnesses, as this is a role generally reserved for the trial court. $I d$. at 272. The factfinder in the trial court sees and hears the witnesses and can observe how they respond to examination, while an appellate court only sees the paper record. $I d$.
} 
justification for a heightened corroboration requirement parallels the justification for a heightened standard of proof. ${ }^{157}$ Although the clear and convincing evidentiary standard used for patent validity is a high standard of proof, it is less rigorous than beyond a reasonable doubt, ${ }^{158}$ which is required in criminal cases. ${ }^{159}$ However, even with a higher standard of proof, criminal courts permit the factfinder to discretionarily evaluate the testimony of a single witness without requiring any corroborating evidence, based on whether the witness is credible and/or impeachable. ${ }^{160}$ For example, even if uncorroborated witness testimony is the only evidence offered by the prosecution, it can support a jury verdict of a crime beyond a reasonable doubt; however, the same uncorroborated testimony cannot support a finding of patent invalidity with clear and convincing evidence. ${ }^{161}$

Additionally, consistent with all bright-line rules, advocates of a strict corroboration rule could argue that Finnigan's standard is easy for courts to apply, gives parties certainty and predictability, ${ }^{162}$ and encourages settlement. A bright-line rule eliminates an unnecessary layer of complexity by preventing the judge from having to evaluate the witness's level of self-interest in the litigation and then weigh the selfinterest against the possibility of inaccurate testimony. ${ }^{163}$ The trade-off, however, is that some credible witness testimony will be insufficient to establish patent invalidity and, in

\footnotetext{
1572 R. Carl Moy, MOY’s WALKER ON PATENTS $\S 8: 71$ (4th ed. 2006).

${ }_{158}$ Buildex, Inc. v. Kason Indus., Inc., 849 F.2d 1461, 1463 (Fed. Cir. 1988).

159 Akhil Reed Amar, Fourth Amendment First Principles, 107 HARV. L. REV. 757,819 n.227 (1994) (“Of course, in a criminal case, the government prosecutor bears the burden of proof beyond a reasonable doubt . ...").

${ }_{160}$ See Hird, supra note 7, at 257-258.

${ }^{161}$ See id.

162 See Mahurkar v. C.R. Bard, Inc., 79 F.3d 1572, 1577 (Fed. Cir. 1996); Schlag, Rules and Standards, 33 UCLA L. REV. 379, 400 (1985).

${ }^{163}$ Hird, supra note 7 , at 283.
} 
general, it will be more difficult for the defendant to assert invalidity as a defense. ${ }^{164}$ Consequently, a bright-line rule for witness corroboration effectively removes what would otherwise be invalidating events from the courts, thereby thwarting the Congressional intent as codified by 35 U.S.C. $\S 102$. Even if patent law may present unique problems relative to other areas of the law, ${ }^{165}$ which arguably creates a heightened incentive for witnesses to testify falsely, victims of criminal cases may have at least an equal or greater incentive to do the same, as much more than financial repercussions or personal vanity is at stake. Thus, an across-the-board corroboration requirement not only overprotects patent interests, but also is irreconcilable with respect to the corroboration standard in other areas of the law.

\section{Application of the Reuter Factors for Single Witness Testimony}

If a more defined structure is needed to shore up patent interests, it is unclear why the court should not employ the Reuter factors to evaluate the credibility of a single witness's testimony, as the Federal Circuit already applies these factors when more than one witness's testimony is involved. If the court applies the Reuter factors to a single witness's testimony, many of the rationales for employing a bright-line rule for corroboration are accounted for, including the interest of the corroborating witness in the subject matter in suit, the extent and details of the corroborating testimony, and the time period between the event and trial. ${ }^{166}$ For example, regarding the Finnigan court's concern that even apparently uninterested witnesses may derive professional or personal

\footnotetext{
${ }^{164}$ See id. at 272.

${ }^{165}$ Particularly in the context of patent validity, witnesses convince themselves to "remember" favorable facts, even if they are honest. Eibel Process Co. v. Minn. \& Ont. Paper Co., 261 U.S. 45, 59-60 (1923). Additionally, even uninterested witnesses may derive a sense of personal or professional accomplishment from being the first in the field. Finnigan Corp. v. ITC, 180 F.3d 1354, 1368 (Fed. Cir. 1999).

${ }^{166}$ See Woodland Trust v. Flowertree Nursery, Inc., 148 F.3d 1368, 1371 (1998) (quoting Price v. Symsek, 988 F.2d 1187, 1195 n.3 (Fed. Cir. 1993) (citing In re Reuter factors)).
} 
accomplishment from being the first in the field, ${ }^{167}$ a court employing the Reuter factors would take this into account under the interest factor, without having to disregard the testimony entirely.

Although Finnigan rejects interest as a relevant consideration when only one witness is testifying, it reinstates interest as a relevant consideration when two witnesses are testifying. ${ }^{168}$ The Finnigan court's elimination of the interest consideration when only a single witness is testifying by labeling all witnesses as interested was likely a simplification of the complexity involved when making this often ambiguous determination. In fact, the different panels in Thomson and Finnigan came to opposite conclusions when trying to determine whether the witnesses in Barbed-Wire were interested or not. ${ }^{169}$ Nonetheless, irrespective of Finnigan, interest is a necessary factor for a court to consider because it goes to the core of the testifying witness's credibility. While an inventor that is a party to the litigation is clearly an interested party, fact scenarios such as Thomson do not present such a clear cut case. Nonetheless, these cases should be left up to the factfinder's discretion. For example, in Thomson, the court acknowledged the witness's potential interest, but did not automatically reject the testimony, noting that the jury had this information and the ability to take it into account in its decision. ${ }^{170}$

\section{CONCLUSION}

In light of the above analysis, Finnigan's bright-line rule for witness

\footnotetext{
${ }^{167}$ See Finnigan, 180 F.3d at 1368.

${ }^{168}$ Finnigan, 180 F.3d at 1369 (noting that Thomson and Woodland Trust correctly recognized that the level of interest of a testifying witness is an important consideration only when such testimony is offered to evaluate the sufficiency of the corroborating evidence).

${ }^{169}$ See supra Part III.A.2.b.

${ }^{170}$ Thomson, S.A. v. Quixote Corp., 166 F.3d 1172, 1174 (Fed. Cir. 1999).
} 
corroboration should be replaced with a more moderate standard that is a natural extension of case precedent and consistent with the requirement's underlying rationale. Thomson provides just that: a middle-of-the-road rule that not only requires a strict standard for inventors and interested parties under $\S \S 102(\mathrm{f})$ and $(\mathrm{g})$, but also gives discretion to the factfinder in cases that do not trigger an automatic application of the rule. In the latter case, the court may use its discretion to determine the credibility of the witness and the resulting value of the witness's testimony, which is consistent with other areas of the law.

Nonetheless, the Federal Circuit should reassess the status of the law regarding the standard for uninterested single witness testimony, as the current state of the law is contradictory and, consequently, has perpetuated uncertainty. Particularly because this issue is frequently at the crux of patent invalidity cases, the standard should be realigned with case precedent and policy as discussed in this article. Whether the Finnigan court was attempting to rectify a general trend against patentees, ${ }^{171}$ the effect of the case has incontrovertibly been to overprotect patent interests, and "[o]verprotecting intellectual property is as harmful as underprotecting it." ${ }^{, 172}$

\footnotetext{
171 See Hird, supra note 7, at 283-84 (citing William C. Rooklidge \& Russell B. Hill, The Law of Unintended Consequences: The On Sale Bar After Pfaff $v$. Wells Electronics, 82 J. PAT \& TRADEMARK OFF. SOC'Y 163, 167, 176 (2000)) (asserting that Finnigan may be consistent with a general trend in the Federal Circuit to restrict the application and effects of the public use and on-sale bars on patentees or alternatively that Finnigan was an attempt to restrict the application of the on-sale bar test after Pfaff led to an increase in the number of findings of patent invalidity by district courts).

${ }^{172}$ White v. Samsung Electronics America, 989 F.2d 1512, 1513 (9th Cir. 1993) (Kozinski, J., dissenting).
} 